\section{Symposium. The economics of conflict: theory and micro-level evidence}

Philip Verwimp (Symposium guest editor)

$F^{\circ}$ or far too long, certain bad outcomes such as war, famine, and genocide where not studied by economists. Based on a core assumption of economics, voluntary exchange in peaceful markets, economists saw violent conflict as an aberration of the main model that did not merit further consideration, theory building, or analysis. Economists neglected the strategic use of violence and force by those who had a comparative advantage in using it.

Two groups of economist, largely independent from each other, changed this unsatisfactory situation. First are scholars in the field of defense and peace economics. Their contributions concentrated on the analysis of the arms race, the military-industrial complex, arms sales, military expenditure, nuclear arms control, and related topics. These topics came to the forefront during the Cold War, a period in which academics and policymakers were very much occupied with interstate war, alliances, and nuclear arms. Today, this problematic is still with us, witness the invasions of Afghanistan and Iraq, the stand-off between Russia and Georgia, the mounting tension between India and Pakistan, and the nuclear issue in Iran, to name but some interstate conflicts.

After the end of the Cold War, the world has observed an upsurge in another type of conflict, intrastate war. Governments and rebel movements previously held in check by the Cold War superpowers broke out of the straightjacket and sized the opportunity to voice their own long-standing grievances and/or claim their own stake in the affairs of the state. That upsurge has become the center of attention for academic economists and political scientists since the second part of the 1990s.

In the first contribution to this symposium, Mansoob Murshed reviews merits and shortcomings of the intrastate war literature. He acknowledges that the greed versus grievance debate has had an influential impact on researchers and policymakers alike. Murshed argues that the greed versus grievance dichotomy is a useful entry point into the debate about the causes of conflict. In certain instances, where there are substantial quantities of capturable natural resource wealth such as diamonds, oil, or drugs, greed may be the dominant factor prolonging conflict. Without group formation, however, for which some historical grievances are important, violent collective action cannot take place. It follows that conflict analysts should consider greed as well as grievance-based motives with an eye for their potentially salient but different role in the initiation versus the duration of conflict.

Murshed argues that violent conflict is unlikely to take hold if a country has a framework of widely-agreed rules, both formal and informal, that govern the allocation of resources, including resource rents, and the peaceful settlement of grievances. Such a viable social contract can be sufficient to restrain, if not eliminate, opportunistic behavior such as large-scale theft of resource rents, and the violent expression of grievances. The occurrence of large-scale violence thus constitutes a breakdown of the social contract.

Murshed concludes that the competing greed versus grievance hypotheses offer complementary explanations for conflict. Insofar as they do provide alternative views, a fair test for their relative explanatory powers is best conducted at the level of a quantitative country-case study. That is exactly what the three other contributions to this symposium have to offer. The debate in the economics of conflict has been based for a very large part based on cross-country regressions. A third generation of scholars now shifts the debate to the micro-level, to within-country analysis, guided by a thorough understanding of any one country's history and institutions. The focus of this new generation of studies is on the behavior of groups, households, and individuals as drivers, bystanders, or victims of conflict. The three articles each offer such contribution from Latin America, Africa, and Asia.

The article by Ana María Ibáñez argues that the main reasons for forced migration in Colombia are the direct and indiscriminate attacks of which the civilian population is the victim. The population is deliberately attacked. Aggressions against the civilian population allow insurgents to take over valuable assets in order to finance their war operations, but also for their members' personal gain. These attacks also allow the insurgents to strengthen territorial supremacy by driving possible opponents from the region, avoiding civilian resistance, weakening social networks, or separating the civil population from the rebel groups. Kidnappings, massacres, selective murders, forced recruitment, and land mines, among others, are some of the aggressions the civil population face and the strategies used by the rebel groups.

While forced migration is one of the direct consequences of armed conflict worldwide, Ibáñez argues that migration strategies are country-specific. African conflicts are often characterized by a massive flux of people who settle in a refugee camp. In Colombia, most displacement occurs on an individual basis, most municipalities are affected by a certain degree of displacement, displaced people do not migrate out of Colombia and do not settle in refugee camps. This underlines the need for within-country, micro-level analysis. Additionally, in some regions of Colombia there is a close relationship between drug-dealing and displacement when the land acquisition by the former undermines the state's power to mediate conflicts between peasants and landowners.

A second article, by Steven Spittaels and Filip Hilgert, employs a geographic method to study war motivations in the Democratic Republic of the Congo. They argue that greed as well as grievance motivations are present, but that they are not directly related to the control of the mining sector. Warring factions such as the rebellion by Tutsi general Laurent Nkunda and the Democratic Forces for the Liberation of Rwanda (FDLR) are involved in lucrative business ventures but not in 
direct control of the mines themselves. The authors argue that the war strategy of these parties, in particular the control over space, seems to be driven by grievance and security reasons. Tutsi as well as Hutu-affiliated groups feel that their very existence is threatened and seek a territory were they feel safe. Congolese Tutsi claim a stake in the Congolese nation and state whereas Hutu rebels claim a stake in Rwandan politics. A solution to the Congolese situation must thus include a country-specific institutional arrangement that addresses both the politically-based grievances that are at the root of the conflict as well as the economic interests responsible for the duration of the conflict.

The third article, written by Mohammad Zulfan Tadjoeddin and Anis Chowdhury offers a socioeconomic perspective of different forms of conflict in Indonesia. Investigating mainly two kinds of civil strife, to wit, separatist and ethnic/sectarian violence, they argue that the grievance over the loss of a previously superior socioeconomic position is an important driver of these conflicts. To make their claim for separatist violence, the authors focus on the troubled relationship between the central government and the four regions rich in natural resources. They attribute a large chunk of separatist violence to a drive by the central government toward equalization of welfare between the rich and the poor regions, thereby nurturing a feeling of relative loss in the minds of the rich. Tadjoeddin and Chowdhury argue that ethnic/sectarian violence in Indonesia is not explained by widening intergroup horizontal inequality but by three other factors: first, the grievance due to the loss of a group's relative (superior) position vis-à-vis a previously downtrodden group, an explanation thus akin to separatist violence but this time at the intergroup level and not at the interregional level; second, the discrepancy between relatively high levels of education (aspirations) and relatively low levels of welfare (reality); and, third, the increase in local budgets after decentralization making local government posts a prize worth fighting for.

As in the Colombian and Congolese cases, the Indonesia article shows a great need to offer within-country, institution-based analysis of the conflict. Only then can we begin to understand the greed and grievance-based motives of the warring factions.

Note

Philip Verwimp is Research Fellow at the Fund for Scientific Research (Flanders, Belgium) based at the University of Antwerp and Visiting Researcher at Ecares, Université Libre de Bruxelles. He codirects the Households in Conflict Network (www.hicn.org) and can be reached at philip.verwimp@gmail.com. 